\title{
Challenges and Strategies to Improve Tomato Competitiveness along the Tomato Value Chain in Kenya
}

\author{
Sigei K. Geoffrey ${ }^{1}$, Ngeno K. Hillary ${ }^{1}$, Kibe, M. Antony ${ }^{2}$, Mwangi Mariam ${ }^{2} \&$ Mutai C. Mary ${ }^{1}$ \\ ${ }^{1}$ Department of Agricultural Economics and Agribusiness Management, Egerton University, Kenya \\ ${ }^{2}$ Department of Crops, Horticulture and Soils, Egerton University, Kenya \\ Correspondence: Sigei K. Geoffrey, Department of Agricultural Economics and Agribusiness Management, \\ Egerton University, P.O. Box 536-20115, Egerton, Kenya. E-mail: gsigei@ymail.com
}

Received: April 30, 2014

doi:10.5539/ijbm.v9n9p205
Accepted: July 3, 2014

Online Published: August 22, 2014

\begin{abstract}
Tomato (Lycopersicon esculentum mill) is the second leading vegetable in Kenya in terms of production and value after potato. It can be grown either outdoors or under protected environment because of its wide adaptability and versatility. The potential to strategize the ways of enhancing its competitiveness in the value chain remains locked and unexploited due to a host of constraining factors along its value chain, which must be addressed. This paper has identifies the underlying constraints and proposes strategic interventions to enhance tomato competitiveness along the value chain in Kenya. Secondary data was obtained from Horticulture Crop Development Authority, Amiran Kenya limited and Ministry of Agriculture, Livestock and Fisheries records. The data was analyzed using descriptive statistics and presented in tables to ease understanding. Underlying constraints such as production inefficiencies, market inaccessibility, under utilization of processing facilities and consumers exploitation through exorbitant pricing were identified to affect tomato value chain performance. Strategic interventions like the adoption of green house technologies; appropriate irrigation systems, and business model aggregator were identified to enhance tomato value chain competitiveness. Government was therefore recommended to partner with all stakeholders in order to enhance performance in tomato value chain.
\end{abstract}

Keywords: Tomato, value chain, constraints, competitiveness

\section{Introduction}

Horticulture industry is one of the most vibrant sub-sectors of agriculture in the Kenyan economy. It contributes $8 \%$ of the country's GDP and $36 \%$ of the agricultural GDP. Horticulture has continued to grow at an annual rate of $15-20 \%$ over the last decade $(\mathrm{GoK}, 2012)$. The main horticultural crops grown include vegetables, fruits, flowers and nuts.

Tomato (Lycopersicon esculentum mill) is amongst the promising commodities in horticultural expansion and development in Kenya. It accounts for $14 \%$ of the total vegetable produce and $6.72 \%$ of the total horticultural crops (Gok, 2012). Tomato is grown either on open field or under greenhouse technology. Open field production account for $95 \%$ while greenhouse technology accounts for 5\% of the total tomato production (Seminis, 2007). Kenya is among the Africa's leading producer of tomato and is ranked $6^{\text {th }}$ in Africa with a total production of 397,007 tones (FAO, 2012). The major tomato producing Counties in Kenya are Kirinyaga (14\%), Kajiado (9\%) and Taita Taveta $(7 \%)$ as shown in Table 1. 
Table 1. Production of tomato in selected counties in Kenya

\begin{tabular}{lcccc}
\hline \multicolumn{1}{c}{ Counties } & Areas (Ha) & Quantity (Tonnes) & Value (kshs)Millions & Share by quantity \\
\hline Kirinyanga & 1,978 & 54,524 & 1,070 & $13.7 \%$ \\
Kajiado & 1,551 & 36,460 & 990 & $9.1 \%$ \\
TaitaTaveta & 548 & 27,400 & 959 & $6.9 \%$ \\
Meru & 420 & 22,214 & 468 & $5.6 \%$ \\
Bungoma & 1,022 & 21,720 & 887 & $5.5 \%$ \\
Kiambu & 930 & 20,972 & 884 & $5.2 \%$ \\
Migori & 1,068 & 18,429 & 910 & $4.6 \%$ \\
Makueni & 408 & 17,552 & 682 & $4.4 \%$ \\
Homabay & 803 & 13,120 & 638 & $3.3 \%$ \\
Nakuru & 580 & 10,990 & 257 & $2.7 \%$ \\
Machakos & 314 & 10,240 & 357 & 12,840 \\
All counties Total & 18,613 & 397,007 & & $2.6 \%$ \\
\hline
\end{tabular}

Source: HCDA (2013).

Tomatoes exist in two types of varieties: determinate and indeterminate types. Open field production requires determinate varieties like Eden, Onyx, Tanzanite and Monyalla as they are high yielders while Cal. J (Kamongo) albeit being susceptible to diseases, is popular because of its high market value and long shelf-life (Musyoki et al., 2005). The greenhouse production requires indeterminate tomato varieties like Kenom, Marglobe, Monset, Nemonneta and Anna F1 (Odema, 2009).

In Kenya, tomato plays a critical role in meeting domestic and nutritional food requirement, generation of income, foreign exchange earnings and creation of employment. Despite its contribution in poverty alleviation, the tomato industry is faced with a myriad of constraints along its value chain. These include agronomic constraints like incidence of pest and diseases and physiological disorders (cracking, sunburn or scald); institutional constraints like poor post-harvest technologies that has ten perish ability and poorly organized rural and urban market infrastructures that permit unpredictable price fluctuation. These constraints adversely affect the production and marketing of quality tomatoes and should be prudently managed through periodic monitoring and improvement of every function (stakeholder), in order to develop a productive, sustainable and robust tomato value chain. According to Kelley and Byerlee (2004), an estimated $60 \%$ of the Africa's rural population lives in areas of good agricultural potentials, but face poor market access for their agriculture produce. Therefore, improving market infrastructure by providing better and affordable transportation is deemed necessary for enhancing commercialization in developing countries like Kenya (Shilpi \& Umali-Deininger, 2008). The whole portion of tomato produced from Kenya is locally marketed within and around East African countries with nothing left for the international market. The key constraints that cause the dismally export market for Kenyan tomatoes; include poor quality, poor health standards and capricious constant supply of substantially high quantities of the commodity in western markets (Humphrey, 2009). This study therefore underscores the prevailing challenges of quality tomato production and suggests appropriate interventions that have the potential of enhancing the performance of critical stakeholders alongthe tomato value chain.

\section{Methodology}

The paper obtained secondary data from Horticulture Crop Development Authority, Amiran Kenya limited and Ministry of Agriculture, livestock and fisheries records. The data was analyzed using descriptive statistics. The analyzed data were presented in tables.

\section{Results and Discussions}

\subsection{Constraints and Interventions in Tomato Value Chain}

Constraints and possible intervention are provided along the specific functions of value chain namely production; marketing; processing and consumption as given below.

\subsubsection{Production}

Tomato production involves a series of activities from nursery raising, land preparation, planting, field management practices to harvesting. The tomato seeds can be raised in nursery beds, seed boxes or germination plug trays. The nursery site should be chosen where potatoes, brinjals, peppers, and other solanaceous crops have not grown in the last three years due to the risk of crop infection by soil-borne diseases and pest infestations. 
Seedlings are ready for transplanting after one month of germination and are uprooted with a ball of soil at 4 to 6 leaf stage. Production inefficiencies are manifested mainly by poor agronomical practice especially on nutrient management, irrigation, support, pruning, weeding, pest and disease management and harvesting. To enhance tomato performance, an appropriate nutritional program is required. The general principle is to apply phosphate fertilizer as basal dressing for root development. After, transplanting either Urea or calcium ammonium nitrate (C.A.N) are applied to enhance leaf establishment and development. At the onset of flowering, top dressing with higher potassium in N-P-K ratio is necessary for good flowering and fruit setting. In order to correct micro-nutrient deficiencies, foliar feeds can be applied alongside the regular fertilizer applications. Calcium nitrate fertilizer can be applied to avoid blossom end rot disease. Irrigation is an essential factor in tomato development especially during dry season to reduce physiological problems. To prevent disease development, irrigation at night should be avoided. Support is necessary for those varieties with vine which cannot top like indeterminate varieties and these need support by trellising the tomato on poles and wires. Tomato support allows free air movement and reduces moisture accumulation thus reducing disease incidences. Pruning operations are also essential in getting a good yield. Desuckering is the removal of all suckers which are removed by hand as soon as they appear hence frequent surveys around the greenhouse is necessary. Too many leaves increase the canopy cover which may result in high relative humidity hence disease incidences. Old leaves should be removed. Once the tomato fruits are formed, the leaves below this truss should be removed, this operation is called defoliation. Any leaves around the fruit cluster are also removed immediately as they appear. Weed management is required to prevent nutrient competition thereforethe field should be clean at all time. Pest and disease are detrimental to tomato development. Common pests include: aphids, thrips, whiteflies, cutworms, bollworms, leaf miners, spider mites and nematodes. Common disease include: wilts, blight, leaf spots and mildews. Pest can be controlled through pest scouting, weed cleaning, use of certified seed, destroying alternate host inter alia. For disease like mildew and blight copper-based or sulphur fungicide are used. Viral disease can be controlled by controlling vectors like aphids, thrips, whiteflies and nematodes. In addition, tomato production in Kenya occurs mainly in two production seasons from November to February and from April to June with the peak production in May.

\subsubsection{Marketing}

Tomato marketing involves getting the tomato produce from the point of production to the point of consumption. Market inaccessibility has been a major constraint in tomato agribusiness sector. The following are highlightsof major impediments to the market penetration: poor road infrastructures, exorbitant cost of transport, high market price fluctuation, poor or lack of storage facilities and existence of market cartels. Road infrastructures in Kenya especially the rural roads are in very deplorable conditions. Therefore, the government both at the national and county level should improve the road infrastructure to prompt the conveyance of tomato produce from production areas to market destination. In Kenya, existence of cartels in the market has been a bottleneck to competitive marketing process. Cartels have been known for their unjust and iniquitous dominance of the market resulting to poor prices paid to the farmers. The government at both levels should pronounce the cartel networks to be illegal partnerships. Appropriate storage of tomato warrants the safety of tomato for consumption in the right form and at the right time because tomatoes are perishable in nature hence they prone to low shelf-life. In Kenya, availability of tomato storage facilities either among the farmers or traders is limited. Therefore, there is a need for government, traders and farmers to invest in cooling hubs and facilities to prolong the shelf life of fresh tomato produce. High costs of transportation have adversely affected the tomato value chain. High transport costs arise from double taxation by two levels of government, corruption along the highway by traffic police and poor rural roads. Therefore, to reduce high cost of transport the government should initiate unified cess collection system to inhibit double collection of cess. The county government should harmonize legal market charges (licenses) and eliminate illegal charges (bribes) that hinder tomato marketing. The strict measures should also be imposed to the highway traffic police who partake in corruption. Contractual agreement between the farmers and industrial buyers are still weak and this need to be improved. Farmers could do this by lobbying through the members of parliament or civil society organizations for establishment of 'contract violation tax' that would compensate the affected farmers and traders in agricultural contracts.

\subsubsection{Processing}

Tomato processing involves the transformation of fresh tomato produce into the tomato end products like tomato paste, tomato juice, tomato ketchup, tomato sauce inter alia. In Kenya, the major tomato processing industries are Premier food, Njoro canning and Tru food ltd. These industries are located majorly in Nairobi areas except Njoro canning in Nakuru County. Remoteness of tomato processing facilities in major growing areas like Kirinyanga has negatively impacted on the commercialization of tomato. Therefore, the national and private 
investors are encouraged to establish tomato processing plant within the major growing areas. Few or non-availability of local packaging industries have resulted in high cost of packaging material which has directly affected the pricing of the final product. Seasonality of tomato supplies resulting from unpredictable climate and weather changes has compelled the processing industries like Njoro canning to import up to $65 \%$ of semi processed tomato paste from some countries like Egypt. To curb the influx of foreign semi processed tomato paste, the government should enforce stringent measures or policies that protect the local market. Tomato processing industries provide opportunities that should be exploited by the private sector. The possibilities provided by African Growth and Opportunity Act (AGOA) of the United States of America should be explored. The Act provides the Kenya and other African countries the trade preferences for quota and duty-free entry into the United States for agriculture goods in order to expand the benefits under the Generalized System of Preference (GSP) program but enormous work is required by African countries to meet U.S sanitary and phyto-sanitary standards. Currently, South Africa and to a lesser extent Ghana are the only countries enjoying AGOA act for horticulture exports.

\subsubsection{Consumption}

The final chain actor in tomato value chain is consumers and should be treated with utmost respect. Tomato price fluctuations have been the daunting challenge to consumers; these have been caused by fluctuation of supply due to seasonality. Hence, adoption of technologies like irrigation system and greenhouse technology can largely stabilize tomato supply. Another challenge that consumers are facing is perish ability or low shelf life of tomato. It is therefore, imperative for the consumer to invest in cooling facilities like refrigerators to prolong its shelf life. Poor sanitation of tomato produce handling has been also a major impediment for fresh tomato produce from Kenya to reach international standards in terms of production, handling and processing standard. In order to accomplish these standards, all actors in the tomato value chain should comply with Global GAP and HACCP from production to consumption to secure considerable price premiums in the world market. Kenya Bureau of Standards and other food safety regulatory organization should also increase food safety measures by increasing monitoring equipment and also by employing more inspectors in quality control and assurance department. Lastly, government and non-governmental organization should strengthen organization like Consumer Federation of Kenya (COFEK) to lobby for the consumers rights.

\subsection{Strategies to Enhance Competitiveness in Tomato Industry}

The following are the approach suggested for enhancement of the competiveness in tomato value chain.

\subsubsection{Greenhouse Technology}

Greenhouse technology is a viable solution to rural employment. Greenhouse technology adoption in Kenya is still low as only $5 \%$ of tomato is produced under greenhouse. Greenhouse technology is one of the cores of the Agricultural Sector Development Strategies 2010-2020 which seek to boost agriculture production, rural employment and improve food security. According to Makunike (2007), one greenhouse tomato plant has a potential of giving up to $15 \mathrm{~kg}$ at first harvest, going up to $60 \mathrm{~kg}$ by the time it has completed its full cycle, at one year. Farmers can get up to ten folds more yield with greenhouse production system than with open-field pollinated varieties (Seminis-Kenya, 2007). Amiran Kenya limited supply greenhouse kits of various types depending on frame structure, material of the frame and the covering material. Simple plastic greenhouse made of timber and polythene sheets have gained prominence among small-scale tomato farmers in Kenya (Odema, 2009). Their sizes range from $6 \mathrm{~m}$ by $10 \mathrm{~m}$ to $8 \mathrm{~m}$ by $30 \mathrm{~m}$. Some of the various greenhouse sizes and their corresponding yield and estimated costs are given in Table 3 .

A complete greenhouse kit from Amiran Kenya limited comes with collapsible water tank, package of seeds, fertilizers, agrochemicals, trailer training from Amiran's agronomists and insurance for the crops. According to the Amiran farmers, an $8 \times 30$ meters greenhouse can make between Sh350, 000 and Sh550, 000, depending on the crops market. Therefore, the pilot project is expected to take between one or two seasons to break even and start to make profit. The estimate gross margin for tomato production under greenhouse and open field are shown in Table 4 and 5, respectively. 
Table 3. Projection of greenhouse technology

\begin{tabular}{cccccc}
\hline Measurement & Size & No. of plants & $\begin{array}{c}\text { Yields per plant per } \\
\text { season (Kg) }\end{array}$ & $\begin{array}{c}\text { Total yields per unit season } \\
\text { (Tonnes) }\end{array}$ & $\begin{array}{c}\text { Estimated cost of greenhouse } \\
\text { structure }\end{array}$ \\
\hline \multicolumn{7}{c}{ Aluminum tunnel } \\
\hline $8 \times 30 \mathrm{~m}$ & $240 \mathrm{~m}^{2}$ & 1,000 & $15-20(20-40)$ & $15-20(20-40)$ & 190,000 \\
\hline \multicolumn{7}{c}{ Wooden Greenhouse } \\
\hline $6 \times 10 \mathrm{~m}$ & $60 \mathrm{~m}^{2}$ & 300 & $15-20(20-40)$ & $4.5-6(6-12)$ & 60,000 \\
$6 \times 15 \mathrm{~m}$ & $90 \mathrm{~m}^{2}$ & 500 & $15-20(20-40)$ & $7.5-10(10-20)$ & 70,000 \\
$6 \times 20 \mathrm{~m}$ & $120 \mathrm{~m}^{2}$ & 700 & $15-20(20-40)$ & $10-14(14-28)$ & 130,000 \\
$6 \times 25 \mathrm{~m}$ & $150 \mathrm{~m}^{2}$ & 800 & $15-20(20-40)$ & $15-20(16-32)$ & 140,000 \\
$6 \times 30 \mathrm{~m}$ & $180 \mathrm{~m}^{2}$ & 1000 & $15-20(20-40)$ & $7.5-10(20-40)$ & 165,000 \\
\hline
\end{tabular}

Note. Values in parentheses indicate achievable yields with better management practices.

Source: Odame(2009)

Table 4. Gross margin for tomato production under greenhouse technology (one acre)

\begin{tabular}{|c|c|c|c|c|}
\hline & Item & Unit & $\begin{array}{c}\text { Kshs } \\
\text { Unit cost }\end{array}$ & $\begin{array}{c}\text { Kshs } \\
\text { Unit cost }\end{array}$ \\
\hline \multirow[t]{4}{*}{ A } & Construction cost & & & \\
\hline & Green house $30 \mathrm{~m} \times 8 \mathrm{~m}$ wooden & 1 & 208,700 & 208,700 \\
\hline & Irrigation system & 1 & 26,000 & 26,000 \\
\hline & Totalfixed cost & & & 234,700 \\
\hline \multirow[t]{7}{*}{$\mathrm{B}$} & Establishment cost & & & \\
\hline & Seedling & 1000 & 2.00 & 2,000 \\
\hline & Pesticides (insecticides, fungicide) & & 7,000 & 7,000 \\
\hline & Growth hormone( flowering) & & 2,000 & 2,000 \\
\hline & Fertilizer DAP, CAN, Foliar Feed & $25 \mathrm{~kg}$ & 200 & 5,000 \\
\hline & Manure & 3 tonnes & 1,500 & 4,500 \\
\hline & Totalvariable cost & & & 20,500 \\
\hline \multirow[t]{6}{*}{$\mathrm{C}$} & Expected revenue & & & \\
\hline & 1000 Tomato plants@20kgs & $20,000 \mathrm{~kg}$ & 20 & 400,000 \\
\hline & Total cost & & & 255,200 \\
\hline & Gross margin $\left(240 \mathrm{~m}^{2}\right)$ & & & 144,800 \\
\hline & Gross margin (one acre) & & & $1,508,333$ \\
\hline & NB: Labour costs for management not included & & & \\
\hline
\end{tabular}

Source: Amiran website.

Table 5. Gross margin for tomato (Cal J) underopen field production

\begin{tabular}{|c|c|c|c|c|}
\hline Item & Unit & Quantity & Unit cost & Total cost \\
\hline Land preparation & One acres & 1 & 2,500 & 2,500 \\
\hline Seeds & 100 gram & 2 & 400 & 800 \\
\hline Chemicals & & & & 13,500 \\
\hline Nursery management & Labour (MD) & 4 & 250 & 1,000 \\
\hline $\begin{array}{l}\text { Land preparation, planting } \\
\text { and fertilizer application }\end{array}$ & Labour (MD) & 26 & 250 & 6,500 \\
\hline $\begin{array}{l}\text { Weeding }(1,2,3) \text { and top } \\
\text { dressing }\end{array}$ & Labour (MD) & 36 & 250 & 9,000 \\
\hline Spraying & Labour (MD) & 6 & 250 & 1,500 \\
\hline Watering (irrigation) & Labour (MD) & 10 & 250 & 2,500 \\
\hline Harvesting and grading & Labour (MD) & 70 & 250 & 17,500 \\
\hline Market preparation & Labour (MD) & 18 & 250 & 4,500 \\
\hline Total variables & & & & 46,700 \\
\hline Interest on working capital & Kshs & 0.12 & 46,700 & 5,604 \\
\hline Total gross output & Crate & 400 & 700 & 280,000 \\
\hline \multirow{2}{*}{\multicolumn{4}{|c|}{$\begin{array}{l}\text { Gross margin } \\
\text { NB: } 1 \text { crate contain } 25 \mathrm{Kgs} \text { of tomato }\end{array}$}} & 227,696 \\
\hline & & & & \\
\hline
\end{tabular}

Source: Ministry of Agriculture, Nakuru County (2014). 


\subsubsection{Irrigation System}

Tomato production under irrigation is the core panacea to curb the seasonal decline and high prices of tomato produce. Kenya has an irrigation potential of 539,000 ha out of which only 105,000 ha (19\%) has been developed for irrigation, leaving 439, 000 ha unexploited (Gok, 2007). Kenya irrigation sector exist in three major categories: public sector which is managed by public agencies, mainly National Irrigation Board and Regional Development Authorities accounts for 12 percent of Kenya's irrigated land; private sector which are commercial high tech schemes mainly irrigating high value crops for export market account for $42 \%$ of the land under irrigation, while smallholder schemes which are owned and managed by farmers under auspices of water users association account for $47 \%$ of total land under irrigation (Gok, 2007). Despite, irrigation potential the sectors are faced with myriads of challenges like inadequate development of irrigation infrastructure and water storage facilities, inadequate support services like financial support and information inadequacies on production. To address this perennial problem of dismal performance on irrigation sector, holistic measures should be put in place by increasing capital investments, improving irrigation support services and provision of capacity building to farmers through training among other avenues.

\subsubsection{Business Model for Aggregator in the Value Chain}

Another strategy to improve the competitiveness of the tomato value chain is the promotion of agro-entrepreneurs as aggregators. These new breed of agro-entrepreneurs will be key in solving the current issues and challenges in tomato value chain which include the following: Fragmented production among large numbers of small farmers with low productivity levels, dispersed small farmers (hence expensive for large companies to provide direct services to the many small holder farmers), side selling tendency of small holder farmers (making it costly and risky for large companies to establish agreements to provide inputs now, procure later and making it difficult for banks to finance farmers in these value chains) and the lack of access to rural finance to support the chain operations and expenses. The model should focus on working with 100 to 500 progressive, small holder farmers, and eventually growing to 1,000 and even over with good management where applicable. The agro-entrepreneur should ideally be a leading producer in the commodity, or a can be risk taking enterprise, or acting for/or a larger agribusiness. The aggregator should be financially stable and should have made profits in the previous years of being in business. They should also belief in building shared values with farmers and other actors along the chain which will translate to good business for aggregator and the others actors too.

\subsection{Model}

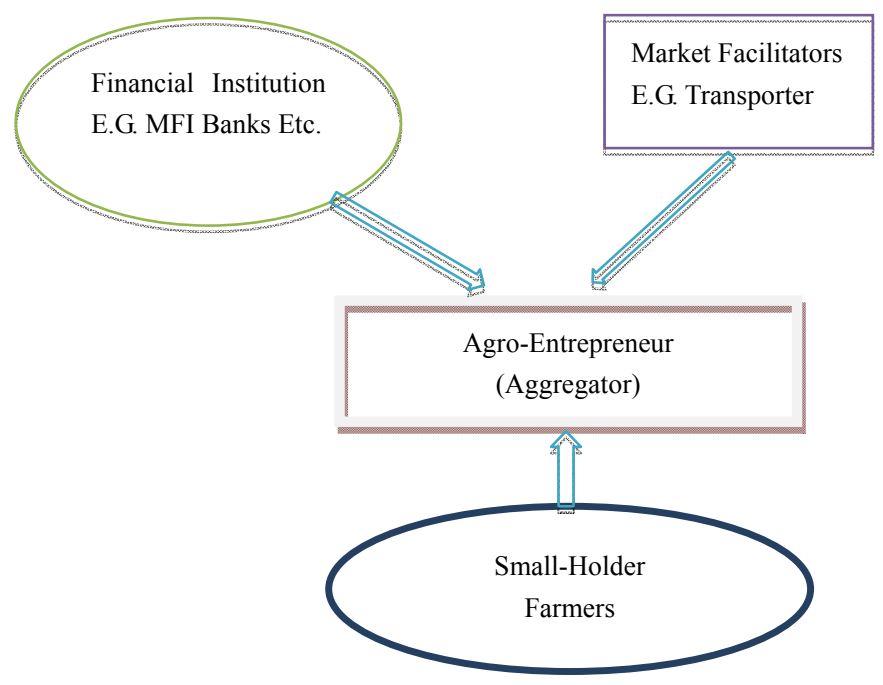

Figure 1. The research model

The agro-entrepreneurs also act as conduits for agricultural finance to smallholder farmers from the financial institutions affiliated to them as they undertake the activities of value chain financing. High performing agro-entrepreneurs, including lucrative social entrepreneurs, can be effective partners in increasing the 
probability of small farmers' success and repayment of loans to the MFI. It is important to note that the agro-entrepreneurs should have the following qualifications: Solid track record of commercial agro-enterprise operations in the targeted commodity group, preferably as a producer, solid track record of procuring from small producers and providing or organizing the needed mix of technical and input supply services, strong management and organizational skills, to be able to put the pieces together for a growing number of small farmers, commitment to adding value to small farmers in ways that will increase their productivity, quality and earnings and ability to work with a significant number of small farmers, from thirty to hundreds or even thousands of small lholder farmers to justify to the financial institution its work to establish cost effective partnerships. This model has been successfully tried and implemented by Njoro Canning Ltd. Njoro Canning has contracted successful large scale farmers who also double up as traders to supply tomatoes to their Njoro Canning Factory. This agro-entrepreneur is mainly from Loitokitok in Kajiado County. They usually have large farms where they plant the tomatoes and to achieve the required volumes they usually aggregate the produce from that area by buying from other farmers within the area and supplying to Njoro Canners Ltd. They usually own large trucks for transportation. The model has also been successfully implemented in parts of Makueni and Taita-Taveta Counties by Care International Ltd. In these counties care has managed to bring and develop farmers' producer associations as well as cooperatives that aggregate the produce from their members for onward sale to traders who then sell to other traders in Nairobi wakulima and Kongowea market in Mombasa. In Kirinyaga and some parts of Muranga County, the model has also been implemented by established producer associations who aggregate and market the produce collectively to processing companies in Nairobi and also to traders targeting the fresh produce markets in Nairobi.

\section{Conclusion and Recommendation}

To conclude, combating with the above bottlenecks and implementing strategic measures of competiveness along the tomato value chain will be vital in poverty alleviation which will help in transforming tomato subsistence production to market oriented production. Therefore, the government both at national and county level are recommended to partner with private sector, financial institutions through public-private partnership initiatives to enable farmers afford quality inputs through appropriate programs such as bulk purchasing and local manufacturing; to invest in road infrastructure developmentthat will promote private investment in all areas of agriculture and facilitate linkage of agriculture to industry; to identify successful models of public-private partnerships (PPP) and business to business (B2B) alliance to raise value chain competitiveness and scale; to invest in transport infrastructure corridors to link high potential production zones and major market areas within and across the regions, to develop quality management, certification services system and harmonize standards, norms and grades across county and national markets; to create partnership opportunities for small scale infrastructure investment in rural areas such as post-harvest and other market related infrastructure to integrate smallholder farmers into local and export value chains; to seek stronger partnerships between leading agribusiness in the county with small enterprises and farmers in the county to promote strong technology and market links in existing and emerging value chains; to eliminate regulatory and administrative barriers and disincentives impeding or raising the unit cost of the movement of goods across local and cross-border markets; and to encourage private investment in production, quality grading, packing, storage, processing and market-related infrastructure to accelerate integration of smallholder farmers into value chains.

\section{References}

FAO (Food and Agricultural Organization). (2012). Statistical Database. Retrieved from http://www.faostat.fao.org

Government of Kenya. (2007). National policy on irrigation and drainage development. Ministry of water and Irrigation policy document.

Government of Kenya. (2012). National Horticulture Policy. Ministry of Agriculture, Kilimo House, Nairobi.

Humphrey, J. (2006). The supermarket revolution in developing countries: tidal wave or tough competitive struggle. Journal of Economic Geography, 7(4), 433-450. http://dx.doi.org/10.1093/jeg/ibm008

Kelley, T., \& Byerlee, D. (2004). Surviving on the margin: Agricultural research and development strategies for poverty reduction in marginal areas. Mimeo, Agriculture and Rural Development, World Bank.

Makunike, C. (2007). Kenya to test greenhouse tomato production model for small scale farmers Africa News Network. Retrieved from http://www.africagricultureblog.com/kenya-to-test-greenhouse-tomato.html

Musyoki, R., Omari, F., \& Mwangi, T. (2005). Evaluation of Elite Tomato Varieties in the Semi-arid regions of Eastern Kenya. KARI Publication. 
Odame, P. S. (2009). Manual on Greenhouse Technology. Agriculture Information Resource Centre. Essensho Company Ltd. Nairobi, Kenya.

Seminis-Kenya. (2007). Retrieved from: http://www.freshplaza.com/news

Shilpi, F., \& Umali-Deininger, D. (2008). Market Facilities and Agricultural Marketing: Evidence from Tamil Nadu, India. Journal of Agricultural Economics, 39(3), 281-294. http://dx.doi.org/10.1111/j.1574-0862.2009.00380.x

Weignberger, K., \& Lumpkin, A. (2005). Horticulture for poverty alleviation: The unfunded revolution. The AVRDC Working Paper Series, No. 15 Taiwan: The World Vegetable Centre.

\section{Copyrights}

Copyright for this article is retained by the author(s), with first publication rights granted to the journal.

This is an open-access article distributed under the terms and conditions of the Creative Commons Attribution license (http://creativecommons.org/licenses/by/3.0/). 